\title{
References
}

1. Markovic, M. R., Salamzadeh, A. "The Importance of Communication in Business Management.” The 7th International Scientific Conference on Employment, Education and Entrepreneurship, Belgrade, Serbia, 2018, pp. 11-28.

2. Colombo, Elizabeth. "Why Better Business Communication Matters and How to Improve It." 2020, www.accdocket.com/why-better-business-communication-matters-and-how-improve-it. Accessed 28 September 2021.

3. Golyardyk, N. A., and L. L. Dyka. "Culture of business communication as a factor in the formation of professional competencies of the future specialist.” Zbirnyk naukovykh prats Natsionalnoi akademii Derzhavnoi prykordonnoi sluzhby Ukrainy, no. 4, 2013, pp. 78-86.

4. Zotova-Sadilo, O. "Methodological aspects of formation of professional business communication of future economic specialists.” Liudynoznavchi studii, no. 2, 2016, pp. 75-82.

5. Krasnitskaya, G. M. "Ethical and business relations of businessmen.” Molodyi vchenyi, no. 4 (31), 2016, pp. 310-313.

6. Savenkova, L. "Formation of the culture of professional communication of future managers of economic education.” Vytoky pedahohichnoi maisternosti, no. 15, 2015. pp. 31-34.

7. Kharchenko, L. P. "Perception and mutual understanding in the context of ethics of business communication.” Visnyk Luhanskoho natsionalnoho universytetu imeni Tarasa Shevchenka, no. 22 (8), 2012, pp. 40-48.

8. van Ruler , B. "Communication Theory: An Underrated Pillar on Which Strategic Communication Rests." International Journal of Strategic Communication, no. 12 (4), 2018, pp. 367-381.

9. Bucăţa, G., and A. M.Rizescu "The Role of Communication in Enhancing Work Effectiveness of an Organization.” Land Forces Academy Review, no. 22 (1), 2017, pp. 49-57.

10. Zakaria, H., Kamarudin, D., Hussain, and Y., M. Lazim. "Inclusivity in the Workplace for Persons with Disabilities: Analyzing Communication Effectiveness within Malaysian Companies.” Turkish Online Journal of Qualitative Inquiry, no. 12 (6), 2021, pp. 9717-9726.

11. Jenifer, R. D., and G. P.,Raman.“Cross Cultural Communication Barriers in Workplace.” International Journal of Management, no. 6 (1), 2015, pp. 348-351.

12. Reboulet, A., and R .Jackson. "Effective Communication Approaches for Decision Analytics: An Exploration of Strategies." Effective Strategies for Communicating Insights in Business, 2021. doi: 10.4018/978-1-7998-3964-4.ch002

13. Stacho, Z., Stachová, K., Papula, J., Papulová, Z., Kohnová, L. “Effective communication in organisations increases their competitiveness.” Polish Journal of Management Studies, no. 19 (1), 2019. pp. 391-403.

14. Grinyova, N. Ya., Karpenko, M. O. "Peculiarities of business communication in the implementation of foreign economic activity of the enterprise.” Visnyk Khmelnytskoho natsionalnoho universytetu, no. 6 (3), 2009, pp. 143-146.

15. Avramenko, O. O., Yakovenko, L. V., Shiyka, V. Ya. Business communication. Ivano-Frankivsk, LileiaNV, 2015.

16. Kozyrev, M. P. "Communicative barriers to communication and ways to overcome them." Naukovyi visnyk Lvivskoho derzhavnoho universytetu vnutrishnikh sprav, no. 1, 2014, pp. 201-211.

17. Maksymets, O., and A.Adamovych, "Negotiations as an integral part of business communication." Aktualni pytannia humanitarnykh nauk, no. 36 (2), 2021, pp. 124-128.

УДК 070.631.11:316

doi: 10.15330/apred.1.17.75-83

\section{КОМУНІКАЦІЙНІ АСПЕКТИ УПРАВЛІНСЬКОЇ ПРАЦІ НА ЗАСАДАХ ЛІДЕРСТВА}

Івано-Франківський національний технічний університет нафти і газу, Міністерство освіти і науки України, кафедра менеджменту та адміністрування, вул. Карпатська, 15, м. Івано-Франківськ, 


\author{
76008, Україна, \\ тел.: +380975073311, \\ e-mail: irynagaliuk11@gmail.com, \\ ORCID: 0000-0002-0726-1954
}

тел.:+380666091419, e-mail: verlesya@gmail.com, ORCID: 0000-0002-2509-1194

\begin{abstract}
Анотація. Стаття присвячена дослідженню питання комунікаційного лідерства як інструмента забезпечення ефективної управлінської праці в організації, яка базується на взаємодії «керівник - підлеглий». Авторами проаналізовано змістове наповнення основних категоріальних термінів, які лежать в основі комунікаційного лідерства, а саме комунікативних здібностей та комунікативної компетентності, на основі чого сформовано розуміння комунікативної компетентності лідера. На основі деталізації основних характеристик комунікативної компетентності лідера, представлених у літературі як напрацювання вітчизняних та зарубіжних теоретиків та практиків, та розгляду специфіки комунікативного лідерства при практичній роботі 3 командою авторами доповнено основний перелік комунікативних компетентностей лідера ще однією, а саме здатністю вибору працівників, які мають спільні цінності та подібні життєві позиції, розвитку навичок спільної взаємодії у членів команди на основі єдності життєвих поглядів задля досягнення цілей організації.

Авторами визначено специфіку командної комунікації як визначальної складової в процесі досягнення ефективності спільної роботи та отримання бажаних командних результатів. Зокрема, у статті проаналізовано можливість максимізації рівня ефективності взаємодії «лідер - член команди» на основі урахування основних постулатів, які повинні використовуватись лідером задля активізації зацікавленості до комунікаційних процесів у команді. Дані постулати включають розуміння, насамперед, лідером бажаного результату комунікації, подальшого забезпечення вмотивованості працівників до ефективної командної взаємодії та комунікації, розуміння сенсів усіх процесів, що мають місце в організації.

На основі проведеного дослідження авторами зроблено ряд висновків, основним серед яких $є$ розуміння, що ефективність комунікаційного лідерства визначається здатністю керівника до системного сприйняття процесів, які мають перебіг у організації з метою побудови адекватної комунікаційної структури, яка обов'язковим чином повинна відповідати організаційній структурі. Лише в такому випадку можна досягнути синергетичного ефекту комунікаційної взаємодії в організації.
\end{abstract}

Ключові слова: управлінська праця, комунікативна здатність, комунікативна компетентність, лідерство, комунікаційне лідерство, командні комунікації.

Haliuk I. B., Verbovska L. S.

COMMUNICATION ASPECTS OF MANAGEMENT WORK ON THE BASIS OF LEADERSHIP

Ivano-Frankivsk National Technical

University of Oil and Gas,

Ministry of Education and Science of Ukraine, Department of Management and Administration, street Karpatska, 15, Ivano-Frankivsk, 76008, Ukraine, tel.: +380975073311, e-mail: irynagaliuk11@gmail.com, ORCID: 0000-0002-0726-1954

tel.: +380666091419, e-mail:verlesya@gmail.com, 


\begin{abstract}
The article is devoted to the study of communication leadership as a tool for effective management in an organization based on the interaction "manager - subordinate". The authors analyze the content of the main categorical terms that underlie communication leadership, namely communication skills and communicative competence, based on which the understanding of the communicative competence of the leader is formed. Based on the details of the main characteristics of communicative competence of the leader, presented in the literature as the work of domestic and foreign theorists and practitioners, and consideration of the specifics of communicative leadership in practical work with a team of authors, the main list of communicative values and similar life positions, the development of skills of joint interaction in team members based on the unity of life views in order to achieve the goals of the organization.

The authors identified the specifics of team communication as a determining component in the process of achieving the effectiveness of teamwork and obtaining the desired team results. In particular, the article analyzes the possibility of maximizing the level of effectiveness of interaction "leader - team member" based on the basic postulates that should be used by the leader to enhance interest in communication processes in the team. These postulates include, first of all, the leader's understanding of the desired result of communication, further motivating employees to effective teamwork and communication, understanding the meaning of all processes that take place in the organization.

Based on the study, the authors made a number of conclusions, the main one being that the effectiveness of communication leadership is determined by the ability of the leader to systematically perceive the processes in the organization in order to build an adequate communication structure that must meet the organizational structure. Only in this case it is possible to achieve a synergistic effect of communication interaction in the organization.
\end{abstract}

Key words: managerial work, communicative ability, communicative competence, leadership, communication leadership, team communications.

Вступ. Сьогодні управління обмеженими ресурсами підприємства потребує застосування кваліфікованих підходів до керування процесами раціонального використання виробничого та людського потенціалу задля отримання успіху на ринку шляхом пропозиції якісних товарів та послуг та організації трудової діяльності із урахуванням мотиваційних чинників праці.

Управлінська праця полягає у впливі на колектив з метою отримання бажаних результатів роботи. Якість взаємодії «керівник - підлеглий» визначає рівень ефективності кінцевих результатів роботи. Саме тому особливої ваги набирає питання забезпечення управлінської роботи на засадах лідерства і виховання керівників як лідерів своєї команди.

Особливого значення надається комунікативним навичкам лідера як людини, що вміє вести конструктивний діалог, володіє мистецтвом переконання, вміє вирішити конфліктні ситуації, може просто і доступно донести підлеглим зміст завдань, які перед ними ставляться, забезпечити комунікативну взаємодію всередині колективу.

Значну увагу до питань теоретичного і практичного характеру управлінської праці приділили у своїх працях вітчизняні вчені Балабанова Л. В. і Сардак О. В. [1], Виноградський М. Д., Виноградська А. М. , Шканова О. М. [2], Завадський Й. С. [3], Новак В. О. [4], Осовська Г. В., Осовський О. А. [5], Скібіцька Л.І. [7], Хміль Ф.І. [8], Шегда А.В. [9], та ін. . Водночас окремі питання удосконалення організації управлінської праці на основі розвитку комунікаційних навиків керівника ще не повною мірою вивчені, потребують більш детального дослідження і узагальнення 3 урахуванням основ теорії лідерства.

Теорії лідерства вивчали у своїх працях такі дослідники як: Нестуля О., Нестуля C., Карманенко В. [8], Калашнікова С. [9] та ін. Лідерство як феномен управлінської 
праці розглянуто з різних аспектів, однак комунікаційні компетенції лідера є сферою, яка потребує грунтовнішого вивчення.

Комунікаційние лідерство є доволі новим напрямом дослідження. Основними вітчизняними та зарубжними представниками є Гузар О. [10], Пашко Л. [11], Йохансон К., Міллер В., Гамрін С. [12] та ін. Автори розглядають комунікаційне лідерство як основу ефективної взаємодії, однак розгляд комунікаційного лідерства як інструменті управлінської праці потребує більш ширшого розгляду.

Практика менеджменту показує, що не кожен може бути хорошим керівником, так як і не кожен може бути хорошим комунікатором. Це залежить від характеру людини, їі психотипу, досвіду та особистих установок, бажання вчитися і розвиватися.

Однак, розвиток лідерських та комунікативних навичок дозволяє забезпечувати якісний рівень управлінської праці шляхом ефективної взаємодії між керівником та підлеглими, працівниками всередині колективу. Саме тому питання виховання керівників-лідерів, які спроможні організувати комунікаційні процеси на належному рівні та забезпечити високий рівень управлінської праці, є важливим до реалізації на сьогоднішньому етапі розвитку бізнес-середовища.

Постановка завдання. Метою даної статті $\epsilon$ ідентифікація основних комунікаційних компетенцій лідера, які дозволяють забезпечити якісний перебіг процесів реалізації управлінської праці керівника.

Результати. Якісний рівень лідерства базується на організаторських i комунікативних якостях керівника. Здатність людини бути лідером багато в чому залежить від розвиненості у нього організаторських і комунікативних якостей. Управлінська праця потребує певних лідерських здібностей і компетентностей.

Комунікативні здібності - це комплексне багаторівневе особистісне утворення, сукупність комунікативних характеристик особистості, а також iï соціальноперцептивні та операційно-технічні знання та вміння, що забезпечують регуляцію і протікання діяльності спілкування [13, с. 83]. Тобто дані здібності визначають можливість індивіда до забезпечення життєдіяльності на основі спілкування.

Для повноти картини розглянемо визначення комунікативної компетентності.

Комунікативна компетентність - це узагальнена комунікативна властивість особистості, що включає розвинуті комунікативні здібності, сформовані уміння і навички міжособистісного спілкування, знання про основні його закономірності та правила [14, с. 70]. Дане визначення робить акцент на спілкуванні на основі певних базових елементів даного процесу і правил, які його регулюють.

Комунікативна компетентність - багатокомпонентне явище, яке складається iз сукупності знань, умінь і якостей, необхідних для міжособистісної, міжкультурної та ділової комунікації в конкретних соціальних умовах, відповідно до культурних i соціальних норм комунікативної поведінки й комунікації з масовим адресатом [15, с. 70]. В даному випадку автор виділяє специфіку спілкування в залежності від умов середовища, в якому воно відбувається, виділяючи специфічні норми поведінки і комунікації у кожному випадку.

Лідерство як необхідна умова управлінської праці частот розглядається 3 точки зору комунікативної складової. Так, Еморі Стівен Богардус (американський соціолог) представляє лідерство у вигляді особливого комунікаційного процесу, в межах якого лідер як суб'єкт впливає на підлеглих, стимулюючи їх до діяльності. При цьому важливим моментом є урахування потреб, інтересів та мети працівників організації, виявити які можливо тільки в процесі якісної комунікації.

У джерелі [16] автори розкривають суть концепції комунікативного лідерства як такої, що аналізує та розвиває комунікативну компетентність лідера. Виділено основні характеристики даної компетентності: 
1) мовна компетентність, яка включає знання мовного коду, в межах якого здійснюється процес комунікації, вміння використовувати усі рівні мови, ії стилістику та правила мовної трансформації;

2) володінням відповідним тезаурусом, тобто володіння запасом слів, які найбільше підходять для комунікації у певній соціально-комунікативній ситуації при спілкуванні на певну тему. Іншими словами, це відкрита і гнучка система значень, які зберігається у пам'яті окремої людини;

3) культурна компетентність, яка передбачає здатність орієнтування у базових елементах культури, ціннісних установках, фонових знаннях, звичаях, ритуалах, стереотипах, які $\epsilon$ притаманні певному соціокультурному середовищу, у якому відбувається процес комунікації;

4) навички спільної (групової) професійної комунікативної діяльності, які $\epsilon$ нормами у певному соціокультурному середовищі згідно стратегій i тактик комунікативної діяльності;

5) прагматична компетентність передбачає вмінням користуватись правилами, максимами, конвенціями спілкування, законами рольової комунікації; когнітивними та інструментальними прийомами, які спрямовані на самоудосконалення особистісної комунікативної діяльності; уміннями проектування ситуації комунікації та вибору ефективних інструментів та стилістики спілкування, відповідно від конкретної ситуації, та розв'язання конфліктних ситуацій;

6) предметна компетентність, тобто розумінням змісту буття зовнішнього i внутрішнього світу та способів їх категоризації в межах конкретної ситуації процесу спілкування;

7) стратегічна компетентність, яка включає навички вибору ефективних стратегій і тактик комунікативної активності в залежності від мети й ситуації комунікаційного процесу;

8) технології комунікативного лідерства, тобто різноманіття моделей вербальної й невербальної комунікації, спрямованих на переконання і спонукання до певних дій, використання множини знаків соціальної інтеграції, уміння адекватної подачі та сприйняття ідей та цінностей, їх деталізація та узагальнення;

9) іллокутивна компетентність характеризується здатністю практичної реалізації комунікативних намірів на основі використання вербальних та невербальних засобів комунікації;

10) представницька комунікативна компетентність передбачає володіння різноманітними комунікаційними технологіями: вербальними, невербальними, поведінковими та іншими, які дозволяють представляти окреме підприємство у взаємодії із елементами зовнішнього середовища: іншими організаціями, громадськістю, ЗМІ та у зовнішній сфері загалом.

Слід відмітити, що результативна ефективність комунікативного лідерства тісно пов'язана із стилем керівництва, який має місце в процесі управлінської діяльності, обраної стратегії взаємодії з командою тощо.

Вважається, що на сьогодні ефективність роботи залежить від командної взаємодії. Недаремно існує вислів: «Якщо ви хочете рухатися швидко, дійте один, але, якщо ви хочете рухатися далеко, дійте 3 командою». Дійсно, робота в команді забезпечує результати, які приходять не відразу. Необхідно витрачати час на навчання людей, пояснення існуючої ситуації та перспективи майбутнього, узгодження дій, нагадування, роботу із саботажем, маніпуляціями, які виникають у команді тощо. Однак, отриманий результат буде значно перевищувати індивідуальний результат.

Особливість формування команди полягає утому, що при підборі іiі членів в основному завертають увагу на знання, навички, компетенції людини. Однак, такі 
особливості як життєві цінності, принципи, установки людини залишаються поза увагою. При цьому слід зауважити, що саме останні визначають поведінку працівника, характер взаємодії з іншими членами команди. Саме тому теорія лідерства на сьогодні зміщує акцент з управління за цілями на управління за цінностями. I відбір членів команди повинен теж відбуватися за цінностями. Експерти вважають, що до $90 \%$ проблем з комунікацією можна вирішити уже на цьому етапі [17]. Адже спільність життєвих принципів та цінностей дозволяє забезпечити краще розуміння один одного, встановлення ефективних контактів та взаємодії.

Таким чином, комунікативна компетентність лідера включає також здатність вибору працівників, які мають спільні цінності та життєві позиції, розвитку навичок спільної взаємодії у членів команди на основі єдності життєвих поглядів.

При цьому завданням лідера $є$ максимальний комунікативний «виграш» усіх членів команди, які залучені до спілкування на задану тематику чи вирішення конкретного питання.

Спілкування у колективі відбувається на постійній основі. Це невпинний процес, який передбачає постановку завдань, обговорення їх виконання, визначення проблемних моментів у роботі, вирішення конфліктних ситуацій тощо. Ефективність комунікаційних процесів зараз i в майбутньому залежить від наявності комунікативного «виграшу» у максимальної кількості учасників даного процесу. Це дозволяє згладити і полегшити процес комунікації у всіх наступних ітераціях, оскільки залучені у роботу працівники відчуватимуть повагу до себе як до особистості, вони ставатимуть більш мотивованими до професійного зростання, взаємодії та подальшого спілкування, а отже і віддача буде максимальною. Відчуття комунікаційного «виграшу» дозволяє відчути удосконалення себе як професіонала, а тому професійна комунікація $\mathrm{i}$ взаємодія переходять на більш якісний рівень.

Комунікація в команді потрібна не просто заради спілкування, а заради результатів. А для забезпечення хороших результатів необхідні люди з високим рівнем мотивації до роботи, хорошими компетенціями та здатністю до інтеграції у команді. Bсе це можна забезпечити за рахунок комунікації. I основна роль у цьому процесі відводиться лідеру як забезпечуючої ланки управлінських процесів.

Спілкування як рутинний процес (наради, ділові розмови, переговори тощо), результатом якого $є$ спілкування заради формальності, давно втратив свою привабливість для працівників. Задля активізації зацікавленості до комунікаційних процесів у команді лідер, як ініціатор кожного виду комунікації, повинен дотримуватись таких основних постулатів:

- окреслення бажаного результату, який він має намір отримати як підсумок спілкування. В іншому випадку буде мати місце просто процес спілкування без окресленого напрямку та мети. Відповідно даний процес не дозволить отримати результатів. Розуміння бажаного результату дозволяє правильно обрати стратегію комунікації, вибудувати іï структуру;

- розуміння позиції учасників комунікації стосовно питання, яке розглядається, стосовно результату, який є намір отримати. Дуже часто опоненти мають відмінні позиції. Тому просто подача інформації із власного аспекту іiі сприйняття не дасть бажаних результатів. В результаті таких дій може бути отриманий супротив, протилежність думок тощо. Переконання в такому випадку буде безрезультатним. Прийняття позиції опонентів дозволяє продемонструвати повагу до їхньої думки та отримати їхню прихильність. I тоді можна разом прослідкувати, який результат може бути отриманий внаслідок тих чи інших дій;

- емоційне налаштування співрозмовників на позитивний лад комунікації. Наприклад, шляхом нагадування про успіхи, які працівники досягнули у минулому. 
Такий позитивний настрой дозволить забезпечити більш плавний і результативний перебіг комунікації;

- сприйняття конфліктної ситуації як позитивного моменту, який викриває проблему. А подолання даного конфлікту сприяє кращій інтеграції, взаємодії та комунікації у команді.

Комунікативний «виграш» дозволяє приймати ефективні командні рішення. Це відбувається внаслідок комунікації на основі «виграв - виграв» для усіх залучених в процес спілкування. Тоді кожен член команди розуміє, що прийняте рішення є вірним, воно відповідає його цінностям і переконанням.

Для забезпечення ефективної комунікації лідеру в його управлінській праці слід акцентувати увагу на таких моментах:

- яким чином відбувається процес комунікації, чи є у ньому прогалини, чи достатня інформованість працівників про стан справ, питання, яке виноситься на розгляд, чи немає дефіциту певного виду інформації тощо;

- який «енергетичний» потенціал має команда до ефективної комунікації. Іншими словами, яка мотивованість працівників до ефективного спілкування. Лише за умови спільного бажання взаємодії буде давати ефект на основі використання навичок та компетентностей працівників;

- які сенси несе кожен процес у організації: виробничий, управлінський, комунікаційний та ін. Неврахування сенсу кожного процесу призводить до ускладнення комунікації.

Урахування перелічених аспектів дозволить чітко визначити структуру, цілі та зміст кожного комунікаційного процесу.

Висновки. На початку даного дослідження мова йшла про якість взаємодії «керівник - підлеглий», яка визначає рівень ефективності кінцевих результатів роботи. У результаті опрацювання даного питання можемо зробити кілька висновків:

1. Управлінська праця передбачає вплив керівника на підлеглих 3 метою отримання бажаний результатів роботи. Вищий рівень ефективності даного процесу може бути забезпечено у форматі взаємодії «лідер - член команди».

2. Успішність та ефективність взаємодії «лідер - член команди» залежить від рівня розвиненості комунікативного лідерства у команді. Комунікаційне лідерство базується на постулатах, які визначають основні комунікаційні компетентності лідера та створюють базис для його розвитку.

3. Ефективність взаємодії «лідер - член команди» залежить від вмотивованості членів команди до побудови ефективних комунікаційних процесів та забезпечення ефективної взаємодії всередині колективу. Наявність ефекту комунікаційного «виграшу» у членів команди створює основу для вмотивованості та бажання будувати комунікаційні процеси, направлені на отримання бажаного результату.

4. Побудова ефективної комунікації у команді - це прерогатива лідера. Саме він, формуючи команду, підбирає іiі учасників «під себе», тобто тих людей, життєві принципи яких збігаються із його поглядами. Саме це дозволяє пришвидшити процеси «притирання» та розуміння працівників один до одного та забезпечити плавність перебігу процесів комунікації.

5. Ефективність командної комунікації залежить від «парних» комунікацій «лідер - член команди». Тому формування команди із людей 3 подібними життєвими цінностями дозволяє забезпечити ефективність як «парних» комунікацій, так i командних.

6. Ефективність комунікаційного лідерства визначається умінням системного сприйняття процесів, що мають місце в організації з метою побудови адекватної 
комунікаційної структури, яка дозволяє отримати синергетичний ефект комунікаційної взаємодії.

1. Балабанова Л. В., Сардак О. В. Управління персоналом: підручник. К.: Центр учбової літератури, $2011.468 \mathrm{c}$.

2. Виноградський М. Д., Виноградська А. М., Шканова О. М. Управління персоналом. 2-ге видання: Навч. посіб. К.: Центр учбової літератури, 2009. 502 с.

3. Завадський Й. С. Менеджмент. Т.1. К.: УФІМБ, 1997. 543 с.

4. Новак В. О., Баклан О. П. Зміст та організація управлінської праці. Еконоліка управління. 2000. №3. C. $42-44$.

5. Осовська Г.В., Осовський О.А. Основи менеджменту: навчальний посібник. К.: "Кондор", 2006. 664 c.

6. Хміль Ф. І. Основи менеджменту: 2-ге видання: підручник. К.:“Академвидав”, 2007. 576 с.

7. Шегда А. В. Менеджмент : підручник. Київ : Знання, 2004. 687 с.

8. Нестуля О., Нестуля С., Карманенко В. Основи лідерства. Тренінг лідерських якостей та практичних навичок менеджера: навч. посіб. К.: Знання. 2013. 287 с.

9. Калашнікова С. А. Освітня парадигма професіоналізації управління на засадах лідерства : монографія. К. : Київськ. ун-т імені Бориса Грінченка, 2010. 380 с.

10. Гузар О. Комунікативне лідерство керівників освітніх закладів : навчальний посібник. К. : ДП «НВЦ «Пріоритети», 2016. 40 с.

11. Пашко Л.А. Управлінське лідерство як запорука ефективності функціонування сфери державного управління. Адміністративна реформа в Україні: сучасний стан, проблеми та перспективи: моногр. За заг. ред. Н.Р.Нижник, Н.Т.Гончарук. Д.: Монолит, 2009. С. 255-271.

12. Catrin Johansson, Vernon D Miller, Solange Hamrin. Communicative Leadership. Theories, Concepts and Central Communication Behaviors. DEMICOM, Mid Sweden University, 2011. 46p.

13. Кулініч І. О. Психологія управління. К., 2011. 415 с.

14. Гавриляк Л. С. Комунікативна компетентність як складова професійної підготовки сучасного фахівця. Науковий журнал «А'ОГОГ. Мистещттво наукової думки». №3. Квітень, 2019. С. 70 - 73.

15. Сидоренко Е. В. Тренинг коммуникативной компетентности в деловом взаимодействии. СПб.: Речь, 2008. 208 с.

16. Бізо Л., Ібрагімова І., Кікоть О., Барань Є., Федорів Т. Розвиток лідерства. За заг. ред. І. Ібрагімової. К. : Проект «Реформа управління персоналом на державній службі в Україні», 2012. $400 \mathrm{c}$.

17. Солодов И. Вторая «рельса» коммуникации в команде. URL: http://solodov.team/tpost/jodghgrp41vtoraya-relsa-kommunikatsii-v-komande (дата звернення: 15.06.2021) .

\section{References}

1. Balabanova L. V., and O. V. Sardak. Personnel management: a textbook. Kyiv, Center for Educational Literature, 2011.

2. Vinogradsky, M. D., Vinogradska, A. M., and O. M. Shkanova. Personnel Management. 2nd ed. Kyiv, Center for Educational Literature, 2009.

3. Zavadsky, Y. S. Management. Vol.1. Kyiv, UFIMB, 1997.

4. Novak, V. O., and O. P.Baklan "Content and organization of management work." Economics of management, no.3, 2000, pp. 42-44.

5. Osovska, G. V., and O. A.Osovsky. Fundamentals of management: a textbook. Kyiv, "Condor", 2006.

6. Khmil, F. I. Fundamentals of Management: 2nd ed. Kyiv, Akademvidav, 2007.

7. Shegda, A. V. Management: a textbook. Kyiv: Znannia, 2004.

8. Nestulya, O., Nestulya, S., and V. Karmanenko. Fundamentals of leadership. Training of leadership qualities and practical skills of a manager. Kyiv, Knowledge. 2013.

9. Kalashnikov, S. A. Educational paradigm of professionalization of management on the basis of leadership. Kyiv, Borys Hrinchenko University, 2010.

10. Husar, O. Communicative leadership of heads of educational institutions: a textbook. Kyiv, DP "Scientific and Production Center" Priorities ", 2016.

11. Pashko, L. A. "Management leadership as a guarantee of effective functioning of public administration." Administrative reform in Ukraine: current status, problems and prospects: monograph, ed. N.R. Nizhnik, N.T. Goncharuk. Dnipro: Monolith, 2009, pp. 255-271.

12. Johansson, Catrin, Miller, Vernon D, and Solange Hamrin. Communicative Leadership. Theories, Concepts and Central Communication Behaviors. DEMICOM, 2011.

13. Kulinich, I. O. Psychology of management. Kyiv, 2011. 
Актуальні проблеми розвитку економіки регіону. Вип 17. Т.1

14. Gavrilyak, L. S. "Communicative competence as a component of professional training of a modern specialist." Scientific journal "К'ОГО $\Sigma$. The art of scientific thought, no.3, 2019, pp. 70 - 73.

15. Sidorenko, E. V. Training of communicative competence in business interaction. SPb,Rech, 2008.

16. Bizo, L., Ibragimova, I., Kikot, O., Baran, E., and T. Fedorov. Leadership development, ed. I. Ibragimova. Kyiv, Project "Personnel Management Reform in the Civil Service in Ukraine", 2012.

17. Solodov, I. "The second "rail" of communication in the team." Solodov.team, solodov.team/tpost/jodghgrp41-vtoraya-relsa-kommunikatsii-v-komande. Accessed 15 June 2021. 